\title{
The Impact of Consumer Perception on Purchase Decision of XL Xtra Combo Lite Data Package Card
}

\author{
Onita Sari Sinaga \\ Sekolah Tinggi Ilmu Ekonomi Sultan Agung \\ onitasari@stiesultanagung.ac.id
}

\section{Debi Eka Putri}

Sekolah Tinggi Ilmu Ekonomi Sultan Agung debiekaputri@stiesultanagung.ac.id

\section{Marto Silalahi}

Sekolah Tinggi Ilmu Ekonomi Sultan Agung martosilalahi@stiesultanagung.ac.id

\begin{abstract}
Abstrak The objective of this study was to determine the effect of consumer perception on purchase decision of XL Xtra Combo Lite data package card (a case study of the VI semester students of Management Study Program at the STIE Sultan Agung). This study used the designs of literature review and field research. The type of data used in this study was qualitative and quantitative data. The data sources consisted of primary data and secondary data. The population used in this study was the VI semester students of undergraduate Management Study Program at the STIE Sultan Agung and the sample used was 44 respondents. The data collection was carried out by questionnaire, interview and documentation. The analysis technique used was qualitative descriptive and quantitative descriptive analyses consisting of multiple linear regression, correlation test, as well as determination and hypothesis test. The results of this study concluded that consumer perception and purchase decision were good. Then, for the results of the hypothesis, it was known that consumer perception had a positive and significant effect on the purchase decision of XL Xtra Combo Lite data package card (a case study of the VI semester students of Management Study Program at the STIE Sultan Agung).
\end{abstract}

Kata Kunci Consumer Perception, Purchase Decision, Package Card 


\section{INTRODUCTION}

In the changing and dynamic business environment today, it becomes necessary for every business organization to clearly understand and predict consumers different types of behavior when purchasing various products and services to meet their needs (Hanaysha, 2018). One of the signs of the beginning of the era of fast information transfer is the use of unlimited internet access and its flexible characteristics (Lie, et al., 2019). One of the manifestations of the need is reflected in the desire to communicate with companies through telecommunications devices. The need for telecommunications services triggers a lot of demand and supply as well as creates competition among telecommunications service providers. PT XL Axiata Tbk is one of the leading cellular service providers in Indonesia. XL is currently seen as one of the foremost cellular service providers for data and telephone in Indonesia. At present, the Global System for Mobile (GSM) product competition is increasingly tight due to the emergence of various products with the same technology, such as Tri from PT. Hutchinson Charoen Pokphand Telecom, IM3 from PT. Indosat, PT Telkomsel, Tbk, etc.

These conditions illustrate that an individual's purchase intention arises when what is expected matches the reality received. The purpose of purchasing carried out by consumers is also viewed from the marketing tools used by the company. Consumers with pre-purchase purposes turn out to be more interested in promotions than those who do not have purposes. More importantly, pre-purchase targets interact with promotional characteristics and indicate different effects on purchase intention (Xia and Monroe, 2009). Sales promotion is highly prioritized in the market today because consumers prefer to have the effect of persuading themselves in hopes of increasing sales volume and profits (Iranmanesh et al., 2016). Purchase decisions in this study use five dimensions, including: introduction of needs, information search, alternative evaluation, purchase decisions and after-purchase evaluation. In the dimension of alternative evaluation, which is the indicator of trust in the product, there are still many consumers who are unsure of the XL Xtra Combo Lite data package card because some people think that the network is still unstable and it sometimes has problems, such as the signal suddenly disappears and it causes consumers to doubt to purchase the product. In the dimension of the purchase decision, the authors state that the purchase decision of XL Xtra Combo Lite data package card among students is seen to be declining because of the emergence of other competitive products by offering lower rates compared to competitors, such as Axis, IM3, Tri and Telkomsel.

\section{LITERATURE REVEW}

\subsection{Consumer Perception}

Another factor that influences the purchase decision is perception. According to Kotler and Kevin (2009: 340), consumer decision to purchase a product is influenced by the perceptions of the product to be bought. Consumer perception in this study uses three dimensions, including: selective attention, selective distortion, and selective memory. In the dimension of selective attention, there is still a lack of information received in the form of advertisements so that consumers do not know what offers are available, causing them less interested in purchasing the product. In the dimension of selective distortion, consumers find their own information based on past experience of an individual who has used the product so that there are still many consumers who are not satisfied and are not sure to purchase the product. 


\subsection{Purchase Decision}

Information management for customers is very important to carry out in order to know what they expect when they want to decide to purchase a product. Purchase decisions are conditions in which consumers determine or make their decision to purchase and intend to purchase a product. With some of the dynamics that are happening now and seen from the customer aspect, companies have succeeded in creating a new approach in managing communication and interaction with their customers (Hasibuan, et al., 2020). Consumer actions to purchase a product are basically by firstly seeing and evaluating the advantages of the product that will be used that is by looking at the brand image and also the price of the product before making a purchase decision. A study conducted by (Yang, Sarathy and Walsh, 2016), suggested reviews as a tool that influences trust as well as perceptions about future consumer expectations from other important people (reviewers), that is, social consensus or subjective norms.

\section{METHOD}

In this study, the authors used the designs of literature review and field research. This study used a survey method with an explanatory research model using quantitative methods. The research object was the Semester VI students at the STIE Sultan Agung Pematangsiantar who use the XL Xtra Combo Lite data package card. The population of the study was 226 students in semester VI at the STIE Sultan Agung Pematangsiantar. Due to a large number of population, the research sample was taken using a purposive sampling method. The determination of the sample considered several criteria, including that the sample was the user of the XL Xtra Combo Lite data package card more than twice, so that a sample of 44 respondents was selected. The type of data used was qualitative and quantitative data. The data sources were from primary data and secondary data. The research data were collected by conducting interviews, documentation and distributing questionnaires. The data analysis included qualitative data analysis and quantitative analysis. The quantitative analysis included simple linear regression analysis, correlation and determination coefficient and hypothesis testing with a partial test ( $\mathrm{t}$ test).

\section{RESULT}

\subsection{The Overview of Consumer Perception on XL Xtra Combo Lite Data Package Card Consumers}

Overall, the variable of consumer perception had an average value of 3.54 with good answer criteria. The highest value of 3.89 with good answer criteria was for the dimension of selective attention with the indicator of price offer and on the dimension of selective memory with the indicator of the strategic location. The lowest value with an average value of 3.09 with moderate answer criteria was for the dimension of selective attention with the indicator of paying attention to advertisements.

\subsection{The Overview of Purchase Decision on XL Xtra Combo Lite Data Package Card Consumers}

Furthermore, the overall value of the recapitulation of respondents' questionnaires regarding purchase decisions obtained an average value of 3.68 with good answer criteria. Then, the highest average value of 3.91 with good answer criteria was for the dimension of the purchase decision with the indicator of purchasing in another place and on the dimension of after-purchase behavior with the indicator of recommending to others. While the lowest average value of 3.20 with good answer criteria was for the dimension of alternative evaluation with the indicator of trust in the chosen products. 


\subsection{Quantitative Descriptive Analysis}

\subsubsection{Simple Linear Regression Analysis}

This section is to analyze the effect of consumer perception (X1) on the purchase decision (Y) of the XL Xtra Combo Lite data card package on the semester VI students of Management at the STIE Sultan Agung Pematangsiantar. The calculation of data analysis used SPSS version 21, so that the following regression results were obtained:

Table 1

Simple Linear Regression Results

\begin{tabular}{|l|r|r|r|}
\hline \multirow{2}{*}{ Model } & \multicolumn{2}{|c|}{ Unstandardized Coefficients } & Standardized Coefficients \\
\cline { 2 - 4 } & \multicolumn{1}{|c|}{ B } & Std. Error & \multicolumn{1}{c|}{ Beta } \\
\hline \multirow{2}{*}{$\begin{array}{l}\text { (Constant) } \\
1\end{array}$ Consumer } & 29.507 & 5.642 & \\
Perception &, 807 &, 176 &, 578 \\
\hline
\end{tabular}

a. Dependent Variable Purchase Decision

Source: SPSS Statistics version 21 (2019)

Based on the results of regression with SPSS version 21 in table 1 above, it obtained a regression coefficient of $b_{1}$ of 0.807 so that it can be seen that the regression equation obtained was $\hat{\mathrm{Y}}=29.507+0.807 \mathrm{X}_{1}$, meaning that there was a positive effect between the consumer perception on the purchase decision of XL Xtra Combo Lite data package cardon the semester VI students of Management at the STIE Sultan Agung Pematangsiantar.

\subsubsection{Correlation Analysis and Coefficient of Determination}

To find out the strength of the relationship between the consumer perceptions on the purchase decision, a correlation analysis was carried out in the form of the degree or depth of the functional relationship that explained the relationship between the value of $r$. The value of $r$ can be seen through the following table:

Table 2

Correlation Coefficient and Coefficient of Determination

\begin{tabular}{|l|r|r|r|r|}
\hline Model & R & R Square & Adjusted R Square & Std. Error of the Estimate \\
\hline 1 & .578 & .335 & .319 & 5.257 \\
\hline
\end{tabular}

a. Predictors: (Constant), Consumer Perception

b. Dependent Variable: Purchase Decision

Source: SPSS Statistics version 21 (2019)

Based on the results of the regression analysis with SPSS in table 2 above, a correlation of $r=0.578$ was obtained, which means there was a moderate and positive relationship between the consumer perception on the purchase decision of XL Xtra Combo Lite data package cardon the semester VI students of Management at the STIE Sultan Agung Pematangsiantar. The determination coefficient was 0.335, which means the quality of consumers' purchase decision could be explained by $33.5 \%$ by consumer 
perception and the rest $66.5 \%$ was explained by other factors, such as price, promotion, consumer trust, product quality, service quality, and consumer expectations as well as other variables not examined in this study.

\subsubsection{Hypothesis testing}

The next test was the $t$ test. This test was carried out partially to determine whether the hypothesis was accepted or rejected. The effect of the hypothesis was carried out to determine whether the variable of consumer perception tested affected purchase

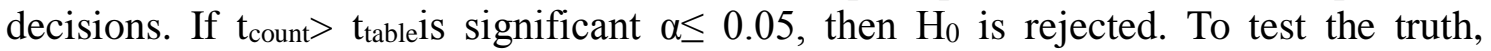
hypothesis testing was carried out using SPSS version 21:

Table 3

The estimated value of $t_{\text {count }}$

\begin{tabular}{|c|c|c|}
\hline Model & $\mathrm{t}$ & Sig \\
\hline Constant & 5.229 & 0.120 \\
\hline Consumer Perception & 4.596 & 0.000 \\
\hline
\end{tabular}

Source: SPSS Statistics version 21 (2019)

Based on table 3 above, it can be seen that the Consumer Perception $\left(\mathrm{X}_{1}\right)$ variable was 4.596> table with $\mathrm{df}=\mathrm{n}-\mathrm{k}-1$ (44-2-1), meaning 3.23 or a significance level of 0.001 $\leq \alpha 0.05$, then $\mathrm{H}_{0}$ was rejected, meaning that the consumer perception had a positive and significant effect on the purchase decision of XL Xtra Combo Lite data package card on the semester VI students of Management at the STIE Sultan Agung Pematangsiantar.

\subsection{Effect of Consumer Perception on Purchase Decision}

Consumer perception is an assessment of a product to influence the sensations it feels. These perceptions can include perceptions of product quality, price, product value, product promotion, etc. Based on the results of the study above, it is obtained that the consumer perception hasan influence on the purchase decision of XL Xtra Combo Lite data package card on the semester VI students of Management at the STIE Sultan Agung Pematangsiantar. These results are in line with studies conducted by Prasetyo, Adrian Yudya, et al. (2018) Kurniasih (2017), Romadhoni (2016) and Saputra (2013), (Isa and Istikomah, 2019), (Hakim and Saragih, 2019), (Putra, Chiwnita and Sarinah, 2019), (Mardiasih, 2019), (Dzulkharnain, 2019), which stated that Perception has a significant effect on purchase decision.

\section{CONCLUSION}

The results of the simple linear regression analysis show that consumer perception has an influence on the purchase decision of XL Xtra Combo Lite data package card. The results of correlation analysis show that there is a moderate and positive relationship between the consumer perception on the purchase decision of XL Xtra Combo Lite data package card on the semester VI students of Management at the STIE Sultan Agung Pematangsiantar. Then, the analysis of the determination coefficient shows that the high and low decisions of purchasing XL Xtra Lite data package card on the semester VI students of Management at the STIE Sultan Agung Pematangsiantar can be explained, one of them is by the level of consumer perception. The results of hypothesis testing with the $\mathrm{t}$ test (partial test) obtained that $\mathrm{H}_{0}$ is rejected, meaning that there is a positive and 
significant effect between the consumer perception on the purchase decision of XL Xtra Combo Lite data package card on the semester VI students of Management at the STIE Sultan Agung Pematangsiantar. To increase the consumer perception on XL Xtra Combo Lite data package card, PT XL Axiata should improve the services provided to consumers so that they have a pleasant experience on this product and need to pay attention to competitors so that consumers do not choose other products and always provide information to customers so that customers know what products and services offered by PT XL Axiata. To increase the purchase decision on XL Xtra Combo Lite data package card, PT XL Axiata should provide clear information about any promos and the package options are offered so that customers more clearly determine and can make purchases.

\section{DAFTAR PUSTAKA}

Dzulkharnain, E. (2019) 'Pengaruh Persepsi Harga, Citra Merek Dan Kualitas Produk Terhadap Keputusan Pembelian', Jurnal Administrasi Bisnis, 1(2), p. 102. doi: 10.14710/jab.v6i2.16611.

Hakim, L. and Saragih, R. (2019) 'Pengaruh Citra Merek, Persepsi Harga Dan Kualitas Produk Terhadap Keputusan Pembelian Konsumen Npk Mutiara Di Ud.Barelang Tani Jaya Batam', Ecobisma (Jurnal Ekonomi, Bisnis Dan Manajemen), 6(2), pp. 37-53. doi: 10.36987/ecobi.v6i2.4.

Hanaysha, J. R. (2018) 'An examination of the factors affecting consumer's purchase decision in the Malaysian retail market', PSU Research Review, 2(1), pp. 7-23. doi: $10.1108 /$ prr-08-2017-0034.

Hasibuan, A. et al. (2020). E-Business: Implementasi, Strategi dan Inovasinya. Cetakan Pertama. Medan: Yayasan Kita Menulis.

Iranmanesh, M. et al. (2016) 'The Effect of Consumer Perception of Volume Discount Benefits on Intention to Purchase Grocery Product: Deal Proneness as a Moderator', Asia Pasific Journal of Marketing and Logistics, 29(5), pp. 1017-1035.

Isa, M. and Istikomah, R. (2019) 'Analisis Perilaku Konsumen Dalam Keputusan Pembelian Makanan di Kota Surakarta', Jurnal Daya Saing, 21(2), pp. 98-110.

Kotler, Philip and Kevin Keller. 2009. Manajemen Pemasaran. Twelfth Edition. Vol. 1. Jakarta: Indeks.

Kurniasih, Rini. (2017). Pengaruh Persepsi terhadap Keputusan Pembelian. Jurnal Administrasi Bisnis. Vol. 49, Number 1, page 128-136.

Lie, D. et al. (2019). Analysis of Mediation Effect Of Consumer Satisfaction On The Effect Of Service Quality, Price and Consumer Trust On Consumer Loyalty. International Journal Of Scientific \& Technology Research, 8(8), pp. 421-428.

Mardiasih, T. S. (2019) 'Pengaruh persepsi harga, kualitas produk, dan lokasi terhadap keputusan pembelian di pasar', Iqtisgadquity, 2(1), pp. 1-10.

Prasetyo, Adrian Yudya, et al. (2018). Pengaruh Persepsi terhadap Keputusan Pembelian. Jurnal Administrasi Bisnis. Vol. 61, Number 3, page 207-214.

Putra, A. I. D., Chiwnita, Oc. and Sarinah (2019) 'Keputusan Pembelian Lipstik Ditinjau dari Persepsi Konsumen pada Mahasiswi Fakultas Ekonomi Universitas Pelita Harapan Medan', Journal of Education, Humaniora and Social Sciences (JEHSS), 2(1), pp. 55-63. doi: 10.34007/jehss.v2i1.53. 
Romadhoni, Syaifuddin. (2016). Pengaruh Persepsi Konsumen terhadap Citra Perusahaan. Jurnal Administrasi Bisnis. Vol. 40, Number 2, page 1-6.

Saputra, Rico. 2013. Analisa Pengaruh Motivasi, Persepsi, Sikap Konsumen terhadap Keputusan Pembelian Mobil Daihatsu Xenia di Sidoarjo. Jurnal Manajemen Pemasaran. Vol. 1, Number 1, page 1-12.

Xia, L. and Monroe, K. B. (2009) 'The influence of pre-purchase goals on consumers' perceptions of price promotions', International Journal of Retail and Distribution Management, 37(8), pp. 680-694. doi: 10.1108/09590550910966187.

Yang, J., Sarathy, R. and Walsh, S. M. (2016) 'Do review valence and review volume impact consumers' purchase decisions as assumed?', Nankai Business Review International, 7(2), pp. 231-257. doi: 10.1108/NBRI-11-2015-0028. 